\title{
SINERGI WAKAF DAN KEUSAHAWANAN DI UNIVERSITY COLLEGE BESTARI
}

\author{
Waqf-Entrepreneurship Synergy at \\ University College Bestari
}

\author{
Mutiara Dwi Sari ${ }^{1}$ \\ Ab. Aziz Yusof ${ }^{2}$ \\ Anura Ibrahim ${ }^{3}$
}

\begin{abstract}
The role of waqf in Higher Education Institutions is currently being discussed. Waqf has proven to be an effective instrument in higher education financing. However, waqf funds need to be optimized to ensure the sustainability of waqf itself. Therefore, all related parties should seek alternatives and solutions to ensure the sustainability of waqf. The first objective of this paper is to examine the management of waqf in higher education institution with a case study at University College Bestari (UCB), Terengganu, Malaysia. Secondly, to analyze issues of waqf sustainability and
\end{abstract}

\footnotetext{
1 Associate Professor, Faculty of Scocial Science, University College Bestari (UCB), 22100 Terengganu, mutiara_dwisari@yahoo.com

2 Professor, Faculty of Ecomonic and Managerment, University College Bestari (UCB), 22100 Terengganu, abaziz.vcucb@gmail.com

3 Senior Lecturer, Faculty of Scocial Science, University College Bestari (UCB), 22100 Terengganu, anura@ucbestari.edu.my
} 
methods used by UCB in ensuring the sustainability of their waqf. This study is qualitative, data was obtained through library research and involving in-depth interviews of two respondents. Data was analyzed using content analysis. The findings have found that, the method used to sustain the waqf funds in UCB is by transparent management of assets through entrepreneurship activities for optimum benefit. The entrepreneurship activities are in the livestock, agriculture and business sectors. Another program is the development of entrepreneurship center within its campus. Besides, the formulation of a teaching and learning curriculum that included entrepreneurship elements was also conducted to ensure that the students have basic entrepreneurial skills. This paper proves that waqf and entrepreneurship are inseparable. The synergies between waqf and entrepreneurship are important as an alternative to the sustainability of waqf itself.

Keywords: waqf sustainability, Higher Education Institutions, waqf productive, entrepreneurship

\section{PENDAHULUAN}

Kedinamikan bidang pendidikantelah dikenal pastisebagai faktorutama penentu kejayaan transformasi Malaysia sebagai sebuah negara maju. Kedinamikan ini menjurus setiap Institusi Pendidikan Tinggi (IPT) untuk merangka, merancang dan melakukan transformasi dalam pendekatan pengajaran dan pembelajaran. Perkara ini bertujuan untuk membangunkan modal insan yang kompeten serta seimbang dengan menyediakan pengajaran dan pembelajaran yang terbaik, berteraskan pembudayaan keusahawanan, mengiktiraf pembelajaran sepanjang hayat bagi kesejahteraan kehidupan masyarakat. Modal insan yang unggul dapat dijadikan sebagai pemangkin bagi kemajuan sebuah negara. Hal ini tentu sahaja memerlukan usaha yang berterusan ke arah membangunkan keupayaan tempatan dan menarik bakat dan pelajar dari pelbagai dunia. Bagi tujuan tersebut, kerajaan telah mengeluarkan peruntukan yang besar untuk melahirkan modal insan kelas pertama dengan memberikan subsidi atau bantuan melalui Kementerian Pendidikan. ${ }^{4}$ Kerajaan telah memperuntukkan perbelanjaan kepada Kementerian Pendidikan sebanyak RM54.6 bilion

4 Tham, S. Y., 'Exploring Access and Equity in Malaysia's Private Higher Education,' A Development Bank Institute (ADBI) Working Paper Series, vol. 28 (2011), 4. 
pada tahun 2014 atau 20.8 peratus daripada jumlah perbelanjaan kerajaan persekutuan dan ini merupakan satu peruntukan kewangan yang agak besar. ${ }^{5}$

Walaupun demikian, terdapat kekangan belanjawan yang dihadapi oleh pihak kerajaan dalam memajukan sektor pendidikan ini. Pembiayaan pendidikan yang mahal dan telah mengekang pelajar untuk mendapatkan pendidikan, terutamanya bagi mereka yang membuat pembiayaan sendiri. Ini menyebabkan tidak semua pelajar mendapat kesempatan untuk mengakses pembelajaran hingga pendidikan tinggi. ${ }^{6}$ Oleh itu, wakaf kini telah menjadi opsyen sumber dana wajib bagi hampir semua IPTA di Malaysia. ${ }^{7}$ Wakaf diyakini sebagai satu strategi yang berpotensi untuk menampung perbelanjaan kerajaan dalam sektor pendidikan yang memainkan peranan penting. ${ }^{8}$ Wakaf memiliki prospek yang tinggi sebagai instrumen atau sumber alternatif pembiayaan sektor IPT. ${ }^{9}$ Wakaf pendidikan tinggi ini dianggap sebagai salah satu solusi yang berpotensi untuk memastikan pendidikan tetap lestari dan dapat dinikmati oleh seluruh masyarakat. Wakaf tidak hanya boleh mengurangkan perbelanjaan awam tetapi pada masa yang sama memenuhi

5 Kementerian Kewangan Malaysia, Bajet 2016 (Kuala Lumpur: KKM, 2016), 3032 .

6 Siti Mashitoh Mahamood \& Asmak Ab Rahman, 'Financing Universities Through Waqf, Pious Endowment: Is It Possible?,' Humanomics, 31/4 (2015): 430-453.

7 Utusan Online, 'Dana Wakaf Kukuhkan Dana Universiti,' http://www.utusan.com. my/berita/nasional/dana-wakaf-kukuhkan-dana-universiti-1.400189, dicapai pada 27 Oktober 2016.

8 Azri Ahmad, Syarqawi Muhammad \& Mohd Asyran Safwan Kamaruzaman, 'Education Development Through Waqf,' (Kertas kerja, 3rd International Conference on Islam and Higher Education (3rd ICIHE), Pahang State Foundation Complex, Kuantan, Malaysia, 1-2 Oktober 2012), 1-22; Siti Zakiah Ali \& Hairunnizam Wahid, 'Peranan dan Kepentingan Dana Wakaf Institusi Pendidikan Tinggi di Malaysia,' (Kertas kerja, Persidangan Kebangsaan Ekonomi Malaysia ke-9 (PERKEM ke-9), Kuala Terengganu, 2014).

9 Asharaf Mohd Romli \& Mustafa Omar Mohamad, 'An Overview of Public Funding for Higher Learning Education in Malaysia and the Prospect of Waqf Funding,' (Waqf Workshop, Contemporary Role of Higher Education, Al-Bukhari International University, Alor Star, 2013), 1-20; Maffuza Salleh \& Noor Syahida Abdul Rahman, 'Wakaf Pendidikan di Malaysia: Satu Tinjauan,' (Kertas kerja, International Research Management and Innovation Conference (IRMIC2014), Kuala Lumpur, 17-18 November 2014), 670-679; Rohayati Hussin, Rusnadewi Abdul Rashid \& Noor Inayah Yaakub, 'Isu-isu berkaitan Tanah Wakaf: Halangan kepada Pembangunan Institusi Wakaf Pendidikan Tinggi di Malaysia,' (Kertas kerja, Waqf Round Table Conference-IKAZ/ACIS, 12 Februari 2015). 
keperluan sosial sesebuah negara. ${ }^{10}$ Oleh itu, wakaf pendidikan merupakan instrumen yang penting dalam pembangunan pendidikan masyarakat Islam. ${ }^{11}$ Mokhtar Ismail et al. menyatakan bahawa wakaf merupakan instrumen yang sangat besar peranannya dalam memberi sumbangan kepada pembinaan dan perkembangan institusi pendidikan dalam dunia Islam. ${ }^{12}$

Institusi pendidikan wakaf ialah sebuah organisasi atau institusi yang ditubuhkan melalui sumbangan masyarakat Islam atau dibina atas tanah atau bangunan yang diwakafkan untuk tujuan pendidikan Islam. ${ }^{13}$ Berdasarkan takrifan tersebut, University College Bestari (UCB) merupakan Institusi Pendidikan Tinggi Swasta (IPTS) berasaskan wakaf yakni dibina berdasarkan sumbangan wakaf. UCB yang menumpukan kepada pendidikan anak yatim dan orang miskin di Malaysia mempunyai visi untuk menjadi sebuah universiti keusahawanan berasaskan wakaf menjelang tahun 2020. Visi ke arah universiti keusahawanan berasaskan wakaf bertujuan untuk membangunkan modal insan yang kompeten serta seimbang dengan menyediakan pengajaran dan pembelajaran yang terbaik, berteraskan pembudayaan keusahawanan, mengiktiraf pembelajaran sepanjang hayat bagi kesejahteraan kehidupan masyarakat.

Isu kelestarian dana wakaf pendidikan tinggi ini sememangnya merupakan masalah tersendiri dan menjadi sorotan beberapa pengkaji dalam bidang wakaf ini. Zakariya Man dan Salihu Abdulwaheed ${ }^{14}$ berhujah, isu yang dipertaruhkan dalam isu kelestarian adalah terkait dengan persoalan bagaimana dana wakaf dapat digunakan dan dimanfaatkan dengan sebaiknya secara cekap dan berkesan. Konsep menggerakkan dana untuk pembangunan

10 Murat Çizakça, 'A Waqf in History and its Implications for Modern Islamic Economies,' Islamic Economic Studies, 6/1 (1998): 43-70; Mohd Syakir Mohd Taib, Wan Kamal Mujani, Ermy Azziaty Rozali \& Kartini AbooTalib@Khalid, 'Perkembangan Wakaf Pendidikan Tinggi di Malaysia Development of Waqf Higher Education in Malaysia,' International Journal of West Asian Studies, 9/1 (2017): 82-92.

11 Maffuza Salleh \& Noor Syahida Abdul Rahman, 'Wakaf Pendidikan di Malaysia: Satu Tinjauan,' 670-683.

12 Mokhtar Ismail, Hairullfazli Muhammad Som, Mohd. Isa Mohd. Deni \& Muna Sulaiman, 'Model Operasi Wakaf Pendidikan di Malaysia,' Prosiding International Conference on Cash Waqf (ICCW 2015) (Sepang: t.p., 2015), 215-228.

13 Maffuza Salleh \& Noor Syahida Abdul Rahman, 'Wakaf Pendidikan di Malaysia: Satu Tinjauan,' 670-683.

14 Zakariya Man \& Salihu Abdulwaheed, 'A New Dimension in the Mobilization of Waqf Funds for Educational Development,' Kuwait Chapter of Arabian Journal of Business and Management Review, 1/1 (2011): 155-175. 
tidak boleh bersifat sementara, sebaliknya ia perlu dilakukan dalam pelbagai cara agar ianya berkekalan. Ini kerana, jikalau wujudnya permasalahan dalam menguruskan aset wakaf pendidikan tinggi, sudah tentu wakaf itu sendiri tidak dapat dilestarikan dengan sebaiknya. ${ }^{15}$ Kelestarian menampung pembiayaan IPT ini amatlah penting kerana proses pendidikan mengambil masa yang panjang dan institusi ini perlu mampu bertahan dalam asakan sektor pendidikan terutamanya yang berkaitan dengan kewangan. Kertas kerja ini mempunyai dua tujuan; pertama, adalah untuk mengenal pasti pengurusan wakaf pendidikan tinggi dengan kajian kes di UCB, Terengganu, Malaysia. Kedua, menganalisis isu kelestarian wakaf dan kaedah-kaedah yang digunakan UCB dalam mempastikan kelestarian wakaf tersebut.

\section{METODOLOGI KAJIAN}

Kajian ini berbentuk kualitatif dengan menggunakan kaedah kajian kepustakaan dan temu bual bagi mengumpulkan data. Data sekunder diperoleh dengan menganalisis intipati karya-karya yang berkaitan dengan wakaf dan keusahawanan. Karya-karya tersebut mengarah kepada konsep pengurusan wakaf di IPT. Tema untuk perkara ini melibatkan dua bentuk kajian. Pertama, kajian yang bersumberkan langsung kepada al-Quran dan hadis. Kedua, kajian yang merujuk kepada sumber-sumber ijtihadi dan kajian-kajian yang telah dijalankan oleh ramai pengkaji sebelumnya dalam bidang wakaf. Data primer pula diperolehi daripada temu bual bersemuka secara mendalam dengan Pengerusi Lembaga Pengelola Universiti (LPU) UCB. Penganalisisan data kajian ini lebih bersifat kualitatif. dengan menggunakan kaedah analisis kandungan. Analisis kandungan merupakan satu kaedah yang digunakan secara meluas dalam bidang penyelidikan yang meliputi pelbagai bidang. Dalam kalangan para penyelidik, analisis kandungan ini mempunyai beberapa kelebihan, antaranya termasuklah tahap sensitivitinya ke atas kandungan teks sesuatu dokumen atau laporan. ${ }^{16}$ Aplikasinya adalah begitu meluas digunakan. Kebolehgunaannya adalah meliputi pelbagai bidang seperti dasar perniagaan dan strategi, kognisi pengurusan dan organisasi, kaedah penyelidikan, tingkah laku organisasi, sumber manusia, teknologi dan pengurusan inovasi, pengurusan

15 Ahmad Shaifful Anuar Ahmad Shukor, Potensi Wakaf Pendidikan Tinggi di Malaysia (Kuala Lumpur: Dewan Bahasa dan Pustaka, 2015).

16 K. Krippendorff, Content Analysis: An Introduction to its Methodology, 3rd. ed. (Thousand Oaks. London: SAGE Publication, 2013), 11. 
antarabangsa dan juga teori organisasi. ${ }^{17}$ Kaedah analisis kandungan ini sesuai digunakan kerana penyelidik boleh menganalisis kandungan catatan-catatan, artikel yang didapati daripada kajian kepustakaan. Kemudian didedahkan secara langsung oleh penyelidik berdasarkan fakta-fakta yang diperolehi. Data yang berbentuk kualitatif yang diperolehi melalui temu bual dianalisis menggunakan kaedah analisis kandungan. Menurut Sabitha Marican, ${ }^{18}$ data yang berbentuk kualitatif atau temu bual boleh dianalisis melalui dua cara: Pertama, analisis kandungan ketara (manifest content) dan analisis kandungan tidak ketara (latent content). Analisis kandungan ketara melihat kepada isi kandungan yang tertera dalam teks atau dokumen sahaja, manakala analisis kandungan tidak ketara memberi peluang kepada penyelidik untuk membuat penilaian dan tafsiran terhadap teks atau dokumen berdasarkan tema kajian dan dalam kajian ini, kedua cara ini turut digunakan.

\section{WAKAF PENDIDIKAN TINGGI}

Murat Çizakça ${ }^{19}$ menyatakan amalan saleh yang bersifat kekal dalam Islam dikenali sebagai wakaf. Menurut Monzer Kahf, ${ }^{20}$ wakaf adalah satu tindakan memegang harta tertentu dan memelihara untuk faedah masyarakat Islam. Syahnaz Sulaiman dan Aznan Hasan ${ }^{21}$ menyatakan, pada asasnya wakaf dan endowmen merupakan dua entiti filantropi yang mempunyai ciri-ciri yang hampir sama iaitu pemberian yang berkekalan dan hanya manfaatnya sahaja yang diagihkan kepada benefisiari yang tertentu. Perbezaan di antara wakaf dan endowment datang dari segi yang paling asas iaitu tasawur dan konsep kepemilikan. Wakaf secara amnya merupakan suatu bentuk pemberian berkekalan atau șadaqah jāriyah yang lahir daripada ruh dan tasawwur Islam yang bertunjangkan kepada dalil al-Quran, al-Sunnah serta ijma' fuqaha, manakala sistem endowmen lahir daripada konsep trust dalam perundangan

17 V.J. Duriau, R.K. Reger \& M.D. Pfarrer, 'A Content Analysis of the content Analysis Literature in Organization Studies: Research themes, data sources, and methodological refinements,' Journal of Organizational Research Methods, 10/1 (2007): 5-34.

18 Sabitha Marican, Penyelidikan Sains Sosial: Pendekatan Pragmatik (Malaysia: Prentice Hall Pearson, 2005), 216.

19 Murat Çizakça, 'A Waqf in History and its Implications for Modern Islamic Economies,' 43-70.

20 Monzer Kahf, 'Financing the Development of Awqaf Property,' (Kertas Kerja, Seminar Development of Awqaf, organized by IRTI, Kuala Lumpur, 1998).

21 Syahnaz Sulaiman \& Aznan Hasan, 'Strategi Pembangunan dan Pelaburan Wakaf secara Lestari Menurut Perspektif Syariah,' Jurnal Syariah, 24/2 (2016): 237-270. 
Inggeris yang tidak bersumberkan nilai atau ruh yang bersifat keagamaan meskipun mempunyai elemen yang berteraskan kebajikan. Daripada konsep pemilikan, aset wakaf dimiliki oleh pemilik asal iaitu Allah SWT dan mutawalli atau pemegang amanah dilantik untuk menguruskan aset wakaf. Sebaliknya bagi sesuatu endowmen, pemegang amanah merupakan pemilik kepada sesuatu endowmen atau trust. Dari segi harta atau objek yang boleh diinfakkan pula, hanya harta yang halal sahaja yang sah untuk diwakafkan manakala endowmen tidak menetapkan hal yang sedemikian. Sehingga aset yang mempunyai elemen riba juga boleh disalurkan. Ini bermakna aset wakaf hanya boleh dikembangkan atau dilaburkan dalam perniagaan yang halal tanpa unsur-unsur batil seperti riba, manakala harta endowmen boleh dilaburkan dalam perniagaan yang bercirikan faedah atau riba bagi menjamin pulangan yang tinggi dan konsisten kepada endowmen tersebut.

Wakaf termasuk amal jariyah yang dituntut dalam Islam berdasarkan alQuran dan hadis Nabi SAW. Allah SWT berfirman:

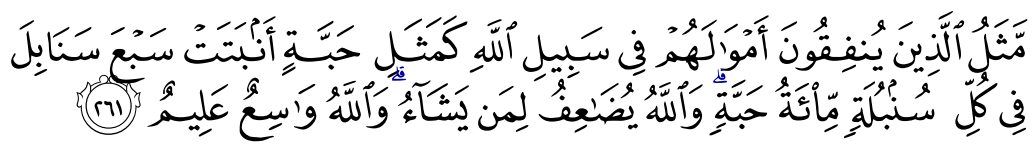

"Bandingan pahala orang yang menafkahkan hartanya di jalan Allah SWT adalah umpama sebiji benih yang menumbuhkan tujuh tangkai dan pada tiap-tiap tangkai itu ada seratus biji dan Allah SWT melipatgandakan (ganjaran) bagi sesiapa yang dikehendaki. Dan Allah Maha Luas (kurniaNya) lagi Maha Mengetahui."

(Surah al-Baqarah, 2: 261)

Selain itu Rasulullah SAW bersabda:

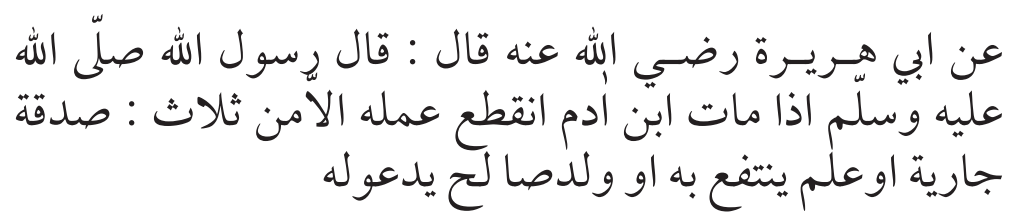

"Diriwayatkan dari Abu Hurayrah, Rasulullah SAW bersabda "Apabila matinya seseorang anak Adam, maka terhentilah amalannya kecuali tiga perkara iaitu kebajikan yang 


\section{berpanjangan (sedekah jariyah), ilmu yang dimanfaatkan dan anak yang soleh yang mendoakannya..." 22}

Berdasarkan kepada nas-nas ini, pemberian wakaf amatlah digalakkan kerana ia seolah-olah membuat pelaburan untuk akhirat di mana pulangan pahala yang berterusan, berkekalan dan berpanjangan walaupun pewakaf telah meninggal dunia. Perkataan șadaqah jāriyah dalam hadis di atas dijelaskan oleh majoriti ulama sebagai wakaf yang berterusan manfaatnya dengan menahan modal dan memanfaatkan hasilnya. ${ }^{23}$ Ini kerana wakaf menjamin kelangsungan amal selama bertahun-tahun, bahkan berabad-abad lamanya setelah kematian pewakaf. ${ }^{24}$ Wakaf terdiri daripada dua jenis iaitu wakaf am dan wakaf khas. Wakaf am merupakan mana-mana bentuk harta wakaf yang dibuat untuk tujuan-tujuan kebajikan atau khairat umum tanpa menentukan mana-mana benefisiari khusus (sama ada terdiri daripada individu ataupun mana-mana organisasi atau institusi) ataupun tujuan-tujuan khusus yang tertentu. Wakaf dalam bentuk ini boleh diaplikasikan kepada perkara-perkara atau tujuan-tujuan kebajikan umum yang dapat meningkatkan lagi imej Islam dan masyarakatnya. Sebagai contoh, seseorang mewakafkan tanahnya untuk tujuan kebajikan umat Islam secara umum tanpa menetapkan sebarang syarat kepada harta yang diwakafkan. Wakaf khas pula bersifat khusus apabila pewakaf menentukan manfaat wakaf yang dibuat untuk tujuan-tujuan khusus ataupun benefisiari-benefisiari tertentu. Sebagai contoh, seseorang pewakaf akan menetapkan kepada siapakah wakafnya dibuat atau untuk tujuan apakah wakafnya mesti dilaksanakan. Misalnya, pewakaf mewakafkan tanah untuk perkuburan atau mewakafkan tanah hanya untuk orang miskin di sesuatu tempat yang dinyatakan. ${ }^{25}$ Maffuza Salleh dan Noor Syahida Abdul Rahman menyatakan bahawa wakaf khas merupakan wakaf yang popular di Malaysia. Pada masa kini kewujudan wakaf seperti wakaf pendidikan, wakaf perubatan, wakaf tempat ibadat, wakaf untuk anak yatim dan fakir miskin

22 Abī al-Ḥusayn Muslim bin al-Hajjāj bin Muslim al-Qushayrī al-Naysabūrī, Șah̄ịh Muslim, vol. 3 (Bayrūt: Dār al-Kutub al-'Ilmiyyah, 1991), no. hadis 1631, dalam "Kitab Wasiat: Bab Pahala Yang diterima oleh Manusia Setelah Mati”. Imam Nawawi menyatakan hadis ini merupakan dalil wakaf serta besarnya pahala wakaf dan menurutnya yang dimaksudkan dengan șadaqah jāriyah adalah wakaf. Lihat Maffuza Salleh \& Noor Syahida Abdul Rahman, 'Wakaf Pendidikan di Malaysia: Satu Tinjauan,' 670-683.

23 Muhammad 'Alī al-Shawkānī, Nayl al-Awṭār, vol. 6 (Manșūrah: Dār al-Wafā', 2005).

24 Murat Çizakça, 'A Waqf in History and its Implications for Modern Islamic Economies,' 43-70.

25 Asmak Ab Rahman, 'Peranan Wakaf dalam Pembangunan Ekonomi Umat Islam dan Aplikasinya di Malaysia,' Jurnal Syariah, 17/1 (2009): 113-152. 
adalah dalam kategori wakaf khas. Wakaf khas ini bersifat khusus apabila pewakaf menentukan wakaf yang dibuat untuk tujuan-tujuan khusus ataupun benefisiari-benefisiari tertentu. Dalam perwakafan khas, seseorang pewakaf akan menetapkan daripada awal lagi kepada siapakah wakafnya dibuat atau untuk tujuan manakah wakafnya mesti diaplikasikan. ${ }^{26}$

Farra Munna Harun et al. ${ }^{27}$ dan Mokhtar Ismail et al. ${ }^{28}$ menyatakan bahawa konsep wakaf telah wujud pada masa Nabi Muhammad SAW dan sejak itu wakaf telah memainkan peranan penting dalam membangunkan tamadun Islam. Wakaf merupakan salah satu bentuk instrumen ekonomi Islam yang memainkan peranan penting dalam pembangunan masyarakat Islam termasuk dalam pembangunan IPT. Mokhtar Ismail et al. ${ }^{29}$ mengatakan bahawa wakaf merupakan instrumen yang sangat besar peranannya dalam memberi sumbangan kepada pembinaan dan perkembangan institusi pendidikan dalam dunia Islam. Univeristi al-Azhar merupakan satu contoh bagaimana wakaf memainkan fungsi penting dalam dunia pendidikan tinggi dan sekali gus merupakan contoh kejayaan wakaf pendidikan tinggi di dunia. Pembangunan Universiti al-Azhar pada awalnya dibiayai melalui dana wakaf dan sehingga kini ia masih lagi diasaskan dan ditadbir melalui sumber wakaf. Selama lebih 800 tahun Universiti al-Azhar ini mampu bertahan yang dibiayai melalui dana wakaf. ${ }^{30}$ Selain daripada Universiti al-Azhar, terdapat contoh-contoh universiti di negara-negara lain yang mendapat manfaat daripada aset wakaf, seperti Universiti Al-Qurawiyin di Fez, Maghribi; Universiti Al-Muntasiriyyah, Iraq; Universiti Cordova, Sepanyol; Universiti Raja Abdul Aziz, UAE dan Universiti Islam Indonesia (UII). Di Cecennestan dan Azerbaijan telah dibangunkan

26 Maffuza Salleh \& Noor Syahida Abdul Rahman, 'Wakaf Pendidikan di Malaysia: Satu Tinjauan,' 670-683.

27 Farra Munna Harun, Bayu Taufiq Possumah, Muhammad Hakimi Mohd Shafiai, Fidlizan Muhammad, Azila Abdul Razak \& Mohd Yahya Mohd Hussin, 'Issues and Economic Role of Waqf in Higher Education Institution: Malaysian Experience,' Journal of Islamic Economics, 8/1 (2014): 149-168.

28 Mokhtar Ismail, Hairullfazli Muhammad Som, Mohd. Isa Mohd. Deni \& Muna Sulaiman, 'Model Operasi Wakaf Pendidikan di Malaysia,' 215-228.

29 Mokhtar Ismail, Hairullfazli Muhammad Som, Mohd. Isa Mohd. Deni \& Muna Sulaiman, 'Model Operasi Wakaf Pendidikan di Malaysia,' 215-228.

30 Azri Ahmad, Syarqawi Muhammad \& Mohd Asyran Safwan Kamaruzaman, 'Education Development Through Waqf,' 1-22; Raja Nor Ashikin Raja Ramli \& Nor 'Adha Abd Hamid, 'Kelestarian Wakaf dalam Membangunkan Institusi Pendidikan: Kajian Awal,' (Kertas kerja, International Conference on Postgraduate Research, Kuala Lumpur, 1-2 Disember 2014). 
masing-masing 800 dan 786 buah universiti yang dibiayai oleh sumber wakaf, manakala di Turki, terdapat sebanyak 142 buah universiti, 87 buah sekolah yang dibangunkan dan dibiayai oleh dana wakaf.

Salah satu universiti terkemuka di Turki ialah Universiti al-Fatih yang dibangunkan dengan dana wakaf. Pada zaman pemerintahan Muhamad al-Fatih Murad, Sultan Muhammad II telah membuat perubahan dengan memastikan pusat-pusat pendidikan dibangunkan melalui sumber wakaf. ${ }^{31}$ Kartini Aboo Talib@Khalid et al. ${ }^{32}$ menyatakan di negara-negara Barat sekalipun amalan endowment telah lama diamalkan di beberapa universiti tersohor dunia termasuk Harvard, Yale, Princeton, Cambridge, dan Oxford. Pengumpulan dana jutaan dollar sebagai modal penggerak dan operasi sangat berkesan bagi universiti tersebut dalam menjalankan khidmat sebagai sebuah IPT. Perkara yang sama juga berlaku di Malaysia. Ahmad Shaifful Anuar Ahmad Shukor ${ }^{33}$ berpendapat bahawa perkembangan IPT Malaysia yang telah melaksanakan wakaf pendidikan tinggi semakin pesat disebabkan telah menjadi kewajipan di setiap universiti untuk melaksanakan wakaf dan telah menjadi salah satu Key Performance Index (KPI) bagi universiti tersebut. Ini adalah kerana instrumen wakaf pendidikan tinggi sangat berpotensi memainkan peranan bagi melestarikan IPT Malaysia di samping membantu universiti dalam mengatasi kos kewangan untuk melaksanakan aktiviti pelajar serta pembangunan IPT yang semakin meningkat. Wakaf pendidikan tinggi ini juga bukan sahaja membantu pembangunan pendidikan pelajar, bahkan membantu IPT daripada segi merangka dasar serta strategi yang mantap agar lebih berdaya saing dan kompetitif kerana adanya faktor kewangan yang kukuh. Pembangunan wakaf pendidikan tinggi semakin mendapat perhatian oleh para pengkaji-pengkaji wakaf di Malaysia. Siti Zakiah Ali, Hairunnizam Wahid, ${ }^{34}$ Siti Mashitoh Mahamood dan Asmak Ab Rahman ${ }^{35}$ menyoroti beberapa IPT di Malaysia yang beroperasi berdasarkan kepada konsep wakaf. Mereka mengatakan terdapat

31 Raja Nor Ashikin Raja Ramli \& Nor 'Adha Abd Hamid, 'Kelestarian Wakaf dalam Membangunkan Institusi Pendidikan: Kajian Awal,' 454-465.

32 Kartini Aboo Talib@Khalid, Nidzam Sulaiman, Wan Kamal Mujani \& Ermy Azziaty Rozali, 'Membiayai Pendidikan Tinggi Menerusi Endowmen: Kewibawaan Model Hibrid Harvard,' Malaysia Journal of Society and Space, 11/4 (2015): 121-131.

33 Ahmad Shaifful Anuar Ahmad Shukor, Potensi Wakaf Pendidikan Tinggi di Malaysia, 110.

34 Siti Zakiah Ali \& Hairunnizam Wahid, 'Peranan dan Kepentingan Dana Wakaf Institusi Pendidikan Tinggi di Malaysia,' (Kertas kerja, Persidangan Kebangsaan Ekonomi Malaysia ke-9 (PERKEM ke-9), Kuala Terengganu, 2014).

35 Siti Mashitoh Mahamood \& Asmak Ab Rahman, 'Financing Universities Through Waqf, Pious Endowment: Is It Possible?,' 430-453. 
sekurang-kurangnya lima universiti yang telah menjalankan operasinya berasaskan wakaf yang melibatkan pelbagai aktiviti, perkhidmatan kebajikan dan program akademik atau profesional. Universiti tersebut adalah Universiti Putra Malaysia (UPM), Universiti Kebangsaan Malaysia (UKM), Universiti Islam Antarabangsa Malaysia (UIAM), Universiti Islam Malaysia (UIM) dan Albukhary Universiti Antarabangsa (AiU).

\section{SINERGI KEUSAHAWANAN DAN WAKAF PENDIDIKAN TINGGI}

Perkataan 'entrepreneur' adalah perkataan Bahasa Inggeris yang bermaksud melakukan sesuatu pekerjaan. Dalam Bahasa Malaysia, istilah usahawan berasal dari perkataan 'usaha'. Menurut Kamus Dewan Edisi Keempat, usaha ialah daya upaya termasuk ikhtiar, kegiatan, perbuatan dan lain-lain hal untuk melaksanakan atau menyempurnakan sesuatu pekerjaan. Secara konvensionalnya, Suraiya Ishak dan Ahmad Raflis Che Omar ${ }^{36}$ menyatakan keusahawanan didefinisikan sebagai proses mengenal pasti peluang-peluang dalampasaran,menyusun sumber-sumberuntukmencapaiobjektifdantindakan, seterusnya mengekploitasi keperluan sumber-sumber bagi kepentingan peribadi dalam jangka masa panjang. Mensinergikan keusahawanan dan wakaf bermakna bagaimana aset wakaf dapat digunakan bagi menciptakan peluangpeluang dalam pasaran bagi kepentingan ummah. Aset wakaf sepatutnya diusahakan dengan memasukkan nilai-nilai keusahawanan di dalamnya agar harta wakaf tersebut lestari dan dapat terus dimanfaatkan. Hal ini selari dengan hadis Rasulullah SAW:

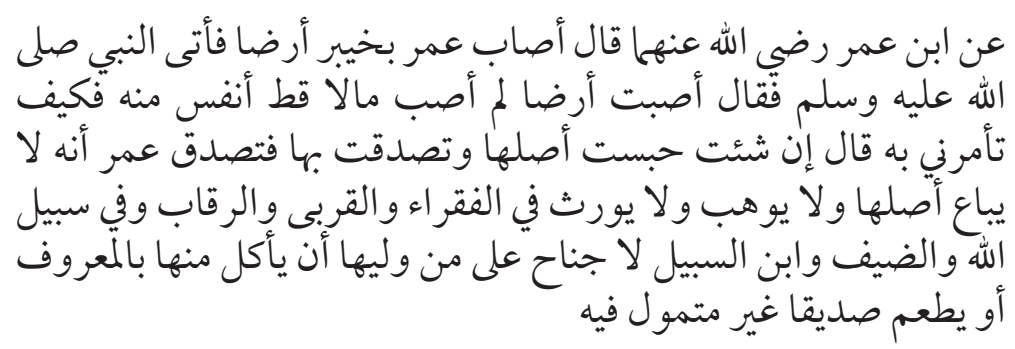

"Daripada Nafi' dari Ibn 'Umar beliau menyebut bahawa Umar RA telah memperoleh tanah di bumi Khaybar. Beliau lalu bertanya kepada Rasulullah SAW: "Wahai Rasulullah, saya telah memperoleh tanah di bumi Khaybar yang nilainya tinggi dan tidak pernah saya peroleh yang lebih tinggi nilai daripadanya. Apakah yang tuan mahu saya lakukannya? Rasulullah SAW bersabda:

$\overline{36}$ Suraiya Ishak \& Ahmad Raflis Che Omar, 'Konsep dan Amalan Perniagaan Sosial di Malaysia,' Jurnal Manusia dan Masyarakat, 2/1 (2015): 55-70. 
"Kalau kamu mahu, bekukan sumbernya dan bersedekah dengannya." Lalu 'Umar menyedekahkan tanah tersebut kepada fakir miskin, kaum keluarganya, untuk memerdekakan hamba, para tetamu dan dana orang musafir. Tanah tersebut tidak boleh dijual, dihibah atau dijadikan pusaka. Tetapi, ia boleh digunakan dengan cara yang munasabah oleh pihak yang menguruskannya. Contohnya, memakan harta tersebut tanpa menjadikannya sebagai sumber harta..." ${ }^{37}$

Merujuk kepada hadis di atas, para fuqaha menetapkan tiga peraturan wakaf yang perlu direalisasikan dalam suatu pelaksanaan wakaf, iaitu harta tersebut tidak boleh dijual, harta tersebut tidak boleh diberikan (dihibahkan) kepada orang lain dan harta tersebut tidak boleh diwarisi. ${ }^{38}$ Berdasarkan hadis ini, terdapat dua prinsip wakaf yang boleh diketengahkan, iaitu prinsip keabadian dan prinsip kemanfaatan. Prinsip keabadian yang dimaksudkan adalah merujuk kepada "tahanlah (bekukan)". Dari sinilah timbulnya syarat bagi harta-harta tahanan atau wakaf yang tidak boleh dijual, dihadiahkan dan diwariskan selama-lamanya. Namun, menahan harta wakaf bagi menjamin kekekalan bukanlah bermaksud membiarkan harta tersebut terpendam atau dimakan lalang tanpa sebarang usaha. ${ }^{39}$ Mereka yang berpegang pada prinsip keabadian percaya bahawa menjaga dan mengekalkan bentuk asal wakaf tersebut merupakan satu kewajipan yang harus dilaksanakan. Oleh itu, harta tersebut tidak boleh diganti dengan sebarang bentuk sekalipun, terutamanya jika harta wakaf itu berbentuk masjid. Manakala prinsip kemanfaatan adalah merujuk kepada "sedekahkan manfaatnya" yang juga membawa maksud manfaat yang bersifat keabadian. Bagi mereka yang berorientasikan prinsip kemanfaatan berpendapat bahawa harta wakaf boleh berlaku pertukaran dan penggantian atas alasan yang kukuh dan munasabah, asalkan manfaat wakaf dapat dikekalkan walaupun melalui harta gantian wakaf tersebut (istibdal).$^{40}$

37 Muḥammad Isma'il al-Bukhārī, Șaḥ̄ḥ Bukhārī (Bayrūt: Dār Ibn Kathīr, 2002), 675, Kitāb al-Shurūṭ, 'Bāb al-Shurūṭ fi al-Waqf,' no. hadis 2737.

38 Muhammad 'Alī al-Shawkānī, Nayl al-Awțār, vol. 6 (Qāhirah: Maktabah wa Matba'ah Muștafā al-Bābī al-Ḥalābī Awlādih, t.t.), 24-29.

39 Syahnaz Sulaiman \& Aznan Hasan, 'Strategi Pembangunan dan Pelaburan Wakaf secara Lestari Menurut Perspektif Syariah,’ 237-270.

40 Jabatan Wakaf, Zakat dan Haji, Manual Pengurusan Istibdal Wakaf (Putrajaya: Jabatan Wakaf, Zakat dan Haji, 2010), 11. 
Akan tetapi menurut Hisham Sabri et al., ${ }^{41}$ hakikatnya kedua-dua prinsip ini saling bersangkut paut. Jika harta wakaf bersifat keabadian, secara tidak langsung manfaatnya juga bersifat keabadian kerana tujuan wakaf adalah untuk memberi manfaat kepada umat Islam seluruhnya. Kajian Siti Inayatul Faizah et al. ${ }^{42}$ mendapati bahawa wakaf berpotensi dalam mengurangkan tingkat pengangguran di Indonesia dengan pemanfaatan aset atau harta wakaf tersebut. Wakaf boleh bertindak sebagai alat untuk menyokong perkembangan ekonomi masyarakat. Kerana dalam instrumen wakaf terdapat semangat saling membantu ( $t a$ 'âwun), dan unsur-unsur pemenuhan kewajiban individu untuk memberikan tanggungjawabnya kepada masyarakat. ${ }^{43}$

Kelestarian wakaf bergantung kepada bagaimana harta wakaf dapat dikelola secara produktif sehingga ianya dapat memberikan manfaat berterusan sesuai dengan sifat wakaf itu sendiri. Oleh itu, pentingnya penerapan nilainilai keusahawanan dalam menguruskan wakaf. Selaras dengan itu, Noor Hisham Md Nawi dan Burhan Che Daud ${ }^{44}$ menggariskan elemen yang perlu ada dalam keusahawanan Islam adalah memperolehi keuntungan dunia dan akhirat (al-falāh). Oleh itu, aset wakaf dapat dimanfaatkan secara optimum bagi memperolehi keuntungan, kemudian keuntungan tersebut dimanfaatkan bagi kemaslahatan ummah. Ini kerana wakaf merupakan suatu konsep yang mempunyai kekuatan dengan struktur yang dinamik dan mekanisme yang fleksibel ke arah melahirkan produk dan perkhidmatan bagi memenuhi keperluan dan kepentingan masyarakat. Wakaf secara tidak langsung menganjurkan nilai pembangunan dan pelaburan yang bersifat holistik dan

41 Hisham Sabri, Khairil Faizal Khairi, Mohamad Yazis Ali Basah, Nurhidayah Laili, Muhamad Ridhwan Abd. Aziz \& Nurhidayah Damiron, 'Sumbangan Manfaat Wakaf Terhadap Pembangunan Ummah di Malaysia: Satu Analisis dalam Pengurusan Johor Corporation (jcorp)-Waqaf An-nur Corporation Berhad (WANCORP), ' ( ${ }^{\text {nd }}$ International Research Management \& Innovation Conference IRMIC 2015, Langkawi, 26-27 Ogos 2015).

42 Siti Inayatul Faizah, Nisful Laila \& Achsania Hendratmi, Productive Waqf as One of the Problematic to Unemployment in Indonesia (Surabaya: ISS \& MLB, 2013), 585-593.

43 Mujtaba Khalid, 'Waqf as a Socially Responsible Investment Instrument: A Case for Western Countries,' European Journal of Islamic Finance, 1 (2014): 1-6.

44 Noor Hisham Md Nawi \& Burhan Che Daud, 'Sinergisme Konsep Wakaf Pendidikan dan Gagasan Keusahawanan Sosial Islam: Wasilah Pembangunan Komuniti Intelektual Mandiri,' dalam Sinergisme Wakaf Pendidikan Tinggi di Malaysia (Shah Alam: Institut Kajian Zakat Malaysia dan Universiti Teknologi MARA, 2016), 85-100. 
lestari yang hasilnya dapat dinikmati dan dituai secara berterusan bukan sahaja di dunia bahkan hingga ke akhirat. ${ }^{45}$

Harta wakaf merupakan amanah yang dipertanggungjawabkan kepada pemegangnya bagi memastikan tujuan dan hasrat asal pewakaf terlaksana. Pemegang amanah seharusnya dapat mengurus, mentadbir dan membangunkan semula harta-harta wakaf. Salah satu jalan untuk kelestarian wakaf itu sendiri adalah melalui aktiviti keusahawanan bagi tujuan meningkatkan nilai aset berkenaan. ${ }^{46}$ Aset wakaf perlulah diikhtiarkan secara optimum sehingga harta tersebut dapat berkembang dan lestari serta dapat memberi manfaat secara optimum. Noor Hisham Md. Nawi dan Burhan Che Daud ${ }^{47}$ menyatakan, amalan wakaf boleh digunakan sebagai instrumen atau aktiviti muamalah Islam yang strategik dengan mengaplikasikan gagasan keusahawanan. Berdasarkan semangat wakaf adalah untuk mendekatkan diri kepada Allah SWT dan pahalanya berterusan kerana manfaat daripadanya juga berterusan. Konsep pembangunan yang bersifat lestari secara amnya telah dijelmakan menerusi konsep wakaf dalam Islam. Entiti wakaf pada dasarnya adalah bersifat "sustainable" (mampan) kerana ditadbir oleh prinsip-prinsip fundamental, iaitu kekal dan tidak boleh dipindah milik atau ditarik balik. ${ }^{48}$

Masyarakat Malaysia sedang dalam proses perubahan daripada masyarakat yang bergantung kepada kerajaan kepada masyarakat yang bekerja sendiri. ${ }^{49}$ Keusahawanan menjadi agenda penting yang dinyatakan dalam Rancangan Malaysia Ke-11. Pembangunan modal insan melalui aktiviti keusahawanan telah dikenal pasti sebagai pembolehubah penting dalam menyokong peralihan

45 Syahnaz Sulaiman \& Aznan Hasan, 'Strategi Pembangunan dan Pelaburan Wakaf secara Lestari Menurut Perspektif Syariah,' 237-270.

46 Hisham Sabri, Khairil Faizal Khairi, Mohamad Yazis Ali Basah, Nurhidayah Laili, Muhamad Ridhwan Abd. Aziz \& Nurhidayah Damiron, 'Sumbangan Manfaat Wakaf Terhadap Pembangunan Ummah di Malaysia: Satu Analisis dalam Pengurusan Johor Corporation (jcorp)-Waqaf An-nur Corporation Berhad (WANCORP),' 1-17.

47 Noor Hisham Md Nawi \& Burhan Che Daud, 'Sinergisme Konsep Wakaf Pendidikan dan Gagasan Keusahawanan Sosial Islam: Wasilah Pembangunan Komuniti Intelektual Mandiri,' 8-100.

48 Mohammad Obaidullah, 'Waqf Development: Islamic Development Bank Experience,' (Kertas kerja, Seminar Wakaf Kebangsaan 2014, Hotel Istana Kuala Lumpur, 7-8 Disember 2014), 1.

49 Norfadhilah Nasharudin \& Halimah Harun, 'Aspirasi Kerjaya Keusahawanan dalam Kalangan Pelajar Institusi Pengajian Tinggi Awam,' Jurnal Pendidikan Malaysia, 35 (2010): 11-17. 
sektor-sektor ekonomi kepada aktiviti berintensif pengetahuan dan inovasi. ${ }^{50}$ Ini bermaksud kerajaan secara tidak langsung telah menggalakkan masyarakat untuk berniaga dan menjadi usahawan. Apabila wujudnya usahawan dalam bidang perniagaan yang dapat menambahkan peluang pekerjaan kepada rakyat Malaysia, maka budaya makan gaji dapat dikurangkan dengan kewujudan usahawan dalam pasaran pekerjaan. ${ }^{51}$ Keusahawanan menjadi satu teras yang amat penting dalam pembangunan sosial dan ekonomi negara di seluruh dunia. ${ }^{52}$ Kepentingan keusahawanan dalam pembangunan ekonomi telah mendorong kerajaan Malaysia menjadikan pelajaran keusahawanan diajar di universiti untuk menggalakkan pelajar menjadikan keusahawanan sebagai pilihan kerjaya mereka setelah tamat pengajian. Modul Pembudayaan Asas Keusahawanan telah disusun dan dilaksanakan di seluruh Malaysia oleh pihak Kementerian Pengajian Tinggi di Institusi Pengajian Tinggi Awam (IPTA). ${ }^{53}$

Noor Hisham Md Nawi dan Burhan Che Daud ${ }^{54}$ telah mengenal pasti konsep konsep wakaf pendidikan berorientasikan keusahawanan sosial Islam. Mereka menyatakan bahawa harta-harta wakaf yang tidak bergerak seperti tanah perlu dilihat melalui perspektif non-tradisional. Secara tradisional, bentuk aset wakaf adalah berkisarkan tanah, rumah, masjid, bangunan. ${ }^{55}$ Kemudian, kebanyakan tanah yang diwakafkan dibiarkan begitu sahaja, tanpa

50 Kementerian Pendidikan Tinggi, Pelan Tindakan Keusahawanan Institusi Pendidikan Tinggi 2016-2020 (Kuala Lumpur: KPT, 2016).

51 Norashidah Hashim, et al., Asas Keusahawanan (Sintok: Pusat Pendidikan Profesional dan Lanjutan (PACE), Universiti Utara Malaysia, 2009), 2-3.

52 Gnyawali R. Devy \& Fogel S. Daniel, 'Environments for Entrepreneurship Development: Key Dimensions and Research Implications,' Entrepreneurship Theory and Practice, 18/4 (1994): 43-62; Hans Landstrom, Pioneers in Entrepreneurship and Small Business Research (New York: Springer ScienceBusiness Media, Inc, 2005), 369.

53 Syahrina, A., Habshah, B., Ooi, Y. K. \& Norashidah, H., 'Kajian Keberkesanan Graduan Ijazah Sarjana Muda Keusahawanan Universiti Utara Malaysia,' (Kertas kerja, Seminar Kebangsaan Pembangunan Keusahawanan, Kuala Lumpur, 8-9 Disember 2009), 89-93.

54 Noor Hisham Md Nawi \& Burhan Che Daud, 'Sinergisme Konsep Wakaf Pendidikan dan Gagasan Keusahawanan Sosial Islam: Wasilah Pembangunan Komuniti Intelektual Mandiri,' 8-100.

55 Hisham Sabri, Khairil Faizal Khairi, Mohamad Yazis Ali Basah, Nurhidayah Laili, Muhamad Ridhwan Abd. Aziz \& Nurhidayah Damiron, 'Sumbangan Manfaat Wakaf Terhadap Pembangunan Ummah di Malaysia: Satu Analisis dalam Pengurusan Johor Corporation (jcorp)-Waqaf An-nur Corporation Berhad (WANCORP),' (2nd International Research Management \& Innovation Conference IRMIC 2015, Langkawi, 26-27 Ogos). 
dimanfaatkan secara maksimum. Ini merupakan cabaran kepada pentadbir wakaf di Malaysia selaku pemegang amanah tunggal untuk membangunkan aset-aset wakaf ini. Kekurangan pengetahuan dalam pengelolaan wakaf mengakibatkan banyak hartanah wakaf masih belum digembleng sewajarnya sehingga masalah kekurangan dana boleh diselesaikan. ${ }^{56}$ Oleh itu, Mohamad Tahir Sabit Mohammad dan Abdul Hamid Mar Iman ${ }^{57}$ mencadangkan agar konsep wakaf bercirikan 'berkekalan' dan 'ketidakbolehan pindah milik' dalam entiti fizikal objek wakaf sepatutnya ditransformasikan kepada konsep yang mengiktiraf 'berkekalan' dedikasi (perpetuity of dedication) menerusi penjelmaan dan pengabadian nilai (value-based waqf). Tindakan ini akan menjadikan pelbagai bentuk harta fizikal dan non-fizikal boleh diterima sebagai objek wakaf dan membolehkan objek berkenaan dipindah milik. Ini juga akan membuka pintu kepada aset cair supaya aktiviti-aktiviti pembiayaan pembangunan dapat dijalankan oleh institusi wakaf dengan lebih mudah. Kefahaman ini membolehkan entiti wakaf yang kekal seperti tanah boleh diusahakan dengan cara kreatif dan memberi manfaat yang lebih besar dan luas dalam bidang pendidikan.

\section{STRUKTUR PENGELOLAAN WAKAF DI UCB}

Merujuk kepada pandangan Chowdhury et al., ${ }^{58}$ kelestarian operasi pada mana-mana organisasi adalah penting dan bergantung kepada kesihatan kewangan. Dalam kes wakaf, perkara ini lebih penting kerana aset yang sepatutnya produktif tetapi dibiarkan terbiar menyebabkan aset tersebut tidak berkembang. Sehingga kini kebanyakan pihak pengurusan wakaf hanya bergantung kepada sumbangan daripada orang ramai dalam menyelenggarakan harta wakaf dan masih kurang inisiatif dalam meningkatkan penghasilan harta wakaf terutamanya yang bersifat ekonomi dan perniagaan. ${ }^{59}$ Sumbangan

56 Syahnaz Sulaiman \& Aznan Hasan, 'Strategi Pembangunan dan Pelaburan Wakaf secara Lestari Menurut Perspektif Syariah,’ 237-270.

57 Mohamad Tahir Sabit Mohammad \& Abdul Hamid Mar Iman, "Obstacles of the Current Concept of Waqf to the Development of Waqf Properties and the Recommended Alternative," Malaysian Journal of Real Estate, vol. 1 (2006): 2738.

58 Chowdhury, M.S.R. et al., 'Economics of Cash Waqf Management in Malaysia: A Proposed Cash Waqf Model for Practitioners and Future Researchers,' African Journal of Business Management, 5/30(2011): 12155-12163.

59 Zakaria Bahari, 'Pembiayaan Pembangunan Pengajian Tinggi: Kes Pembangunan Wakaf Kompleks ISDEV, Universiti Sains Malaysia,' (Kertas kerja, Seminar Serantau Institusi Pengajian Tinggi Islam (SeiPTI2013), Bandar Sri Begawan, 4-5 Disember 2013). 
kerajaan dan masyarakat umumnya tidak dapat dinafikan dalam pembangunan wakaf universiti. Bagaimanapun, cara lain diperlukan untuk memastikan kelestarian wakaf agar tidak terlalu bergantung dengan bantuan kerajaan. University College Bestari (UCB) sebagai salah satu universiti wakaf di Malaysia mempunyai strategi tersendiri bagi memastikan aset wakaf menjadi produktif. UCB yang beroperasi sepenuhnya berasaskan wakaf ini mula mentransformasikan diri dengan menerapkan unsur keusahawanan ke dalam pengurusan wakaf universiti serta mula membangunkan pusat keusahawanan di dalam kampus.

Terdapat beberapa program yang telah dijalankan di UCB. Dalam konteks ini, sinergi wakaf dan keusahawanan dipandang daripada dua sudut. Pertama, bagaimana dana wakaf yang diberikan kepada UCB bagi tujuan pengajaran dan pembelajaran yang berasaskan keusahawanan mampu melahirkan pelajar yang tidak hanya mahir dalam penguasaan teori di bidang masing-masing, malah mempunyai kemahiran keusahawanan. Kedua, pengelolaan dana wakaf yang sedia ada di UCB dalam sektor keusahawanan. Antara program yang telah dijalankan adalah dengan membina kurikulum yang berasaskan keusahawanan. Perubahan kurikulum penting dilakukan akibat adanya perubahan tren pekerjaan yang bergerak dari "to be employed to job creators". Selain itu corak kehidupan, pemikiran, pandangan, gaya hidup dan jangkaan masyarakat yang bersifat dinamik, desakan pelanggan, persaingan peringkat lokal dan global, ketidakstabilan ekonomi serta polisi kerajaan menghendaki suatu universiti merubah paradigma mereka sehingga mampu melahirkan pelajar yang berjiwa keusahawanan.

Bagi mencapai visi ke arah universiti keusahawanan berasaskan wakaf, UCB memandang bahawa perlunya transformasi agar lebih bersedia dengan perubahan-perubahan yang berlaku. Antara transformasi yang dilakukan adalah; 1) Melengkapkan pelajar dengan pelbagai kemahiran terkini yang diperlukan untuk berhadapan dengan cabaran dan merebut peluang di abad ke-21 dan 2) Menyediakan pendidikan berkualiti yang mampu menghasilkan pelajar yang lestari dengan kemahiran kritikal, kemahiran insaniah dan kemahiran keusahawanan dengan memiliki sahsiah diri yang holistik dan seimbang.

Bagi mengurus dan menyelaras perubahan ini, UCB telah menubuhkan Bahagian Pembangunan Usahawan dan Pengajian Bahasa (BestPEC). Melalui bahagian ini, UCB menggalakkan kreativiti dan inovasi dalam kalangan pelajar mahupun pensyarah. Selanjutnya aktiviti pengkomersialan seperti penjanaan kewangan daripada hasil kajian sama ada berbentuk produk atau perkhidmatan kepada kumpulan sasaran juga dijalankan. Contoh aktiviti komersial yang telah dilakukan adalah projek madu kelulut dan sabun kecantikan berasaskan madu. 
Kesemua aktiviti ini bertujuan membekali pelajar dengan pengetahuan dan pengalaman keusahawanan sehingga mereka bukan hanya sekadar menguasai teori, tetapi juga mempunyai kemahiran keusahawanan. Bagi pensyarah pula, BestPEC memberikan suatu latihan atau kursus keusahawanan selama lima hari secara intensif dan dijalankan sekali setiap setahun. Aktiviti-aktiviti sebegini penting bagi tujuan pembelajaran sehingga dapat mengeluarkan pelajar yang mampu menjana pendapatan sendiri sehingga pada akhirnya mereka juga akan menjadi pewakaf terutamanya kepada alma mater mereka sendiri. Langkah ini dinilai berkesan terbukti dengan kejayaan UCB dalam kegiatan keusahawanan di peringkat antarabangsa melalui 2nd International Practice Enterprise Fair in Asia di Seoul, Korea Selatan baru-baru ini yang dianjurkan oleh KoreaPEN dengan kerjasama EUROPEN-PEN International bertemakan Global Enterprise Challenge. Delegasi UCB telah memenangi tempat pertama dalam Global Enterprise Challenge melalui syarikat Trigona Champions Sdn Bhd. UCB turut memenangi tempat kedua dan ketiga dalam The International Trade Show (ITS) dan PE StartUP Challenge bagi kategori 'Best Salesmanship' dan Booth Terbaik. Produk yang dibawa untuk pameran adalah madu trigona dan sabun pelbagai jenis yang dihasilkan sendiri oleh Trigona UCB. ${ }^{60}$

Pengelolaan dana wakaf yang sedia ada di UCB dalam sektor keusahawanan dijalankan dengan pelbagai cara. Hal ini penting bagi memastikan kelestarian UCB dan terus bertahan di tengah ketidaktentuan ekonomi global sekarang. Sebagaimana yang diketahui, tujuan asal wakaf itu sendiri adalah untuk memberikan manfaat kepada masyarakat. Namun, dana wakaf ini perlulah dibangunkan agar aset terus berkembang bagi menambahkan kuantiti wakaf serta kualiti manfaat, di samping struktur dalam organisasi wakaf juga harus jelas bagi memastikan dana wakaf ini dapat dikembangkan dan dikomersialkan. ${ }^{61}$ Isu kelestarian adalah penting kerana proses pendidikan mengambil masa yang panjang dan institusi ini perlu mampu bertahan bagi menampung kos pembiayaan dalam sektor pendidikan. ${ }^{62}$

$\overline{60}$ Utusan Online, 'UCB raih anugerah terbaik di Seoul,' http://www.utusan.com.my/ pendidikan/kampus/ucb-raih-anugerah-terbaik-di-seoul-1.552665, 14 November 2017, dicapai pada 15 Januari 2018; Jabatan Pendaftar dan BestPEC UCB.

61 Siti Zakiah Ali \& Hairunnizam Wahid, 'Peranan dan Kepentingan Dana Wakaf Institusi Pendidikan Tinggi di Malaysia,' (Kertas kerja, Persidangan Kebangsaan Ekonomi Malaysia ke-9 (PERKEM ke-9), Kuala Terengganu, 2014).

62 Mokhtar Ismail, Hairullfazli Muhammad Som, Mohd. Isa Mohd. Deni \& Muna Sulaiman, 'Model Operasi Wakaf Pendidikan di Malaysia,' 215-228. 
Bagi menjelaskan tentang strategi yang dijalankan UCB dalam memastikan kelestarian wakaf dapat dicapai, struktur pengurusan wakaf UCB dipaparkan dalam Rajah 1.

Rajah 1: Struktur Wakaf UCB

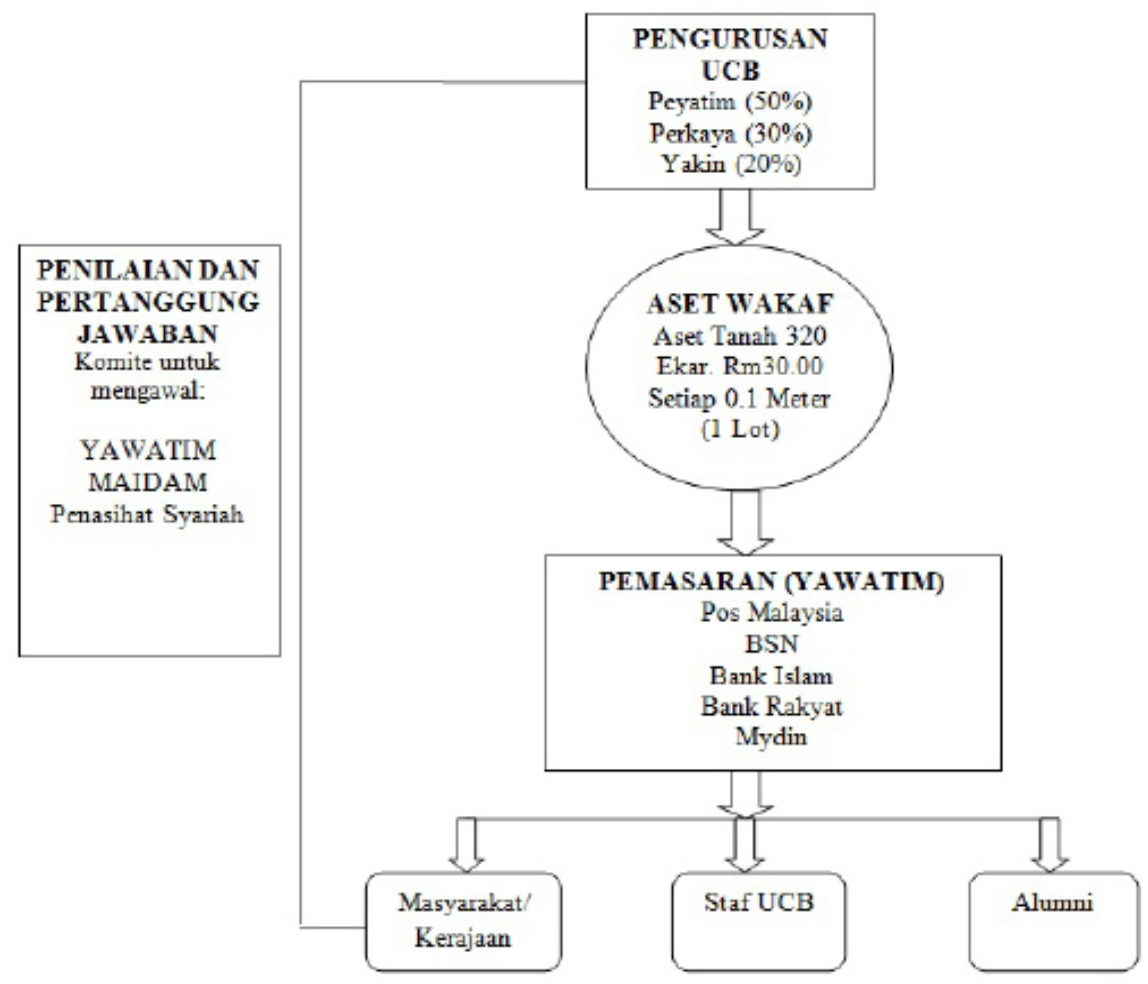

Sumber: Hasil temu bual dengan responden kajian ${ }^{63}$

Berdasarkan Rajah 1, pengurusan dan pentadbiran wakaf UCB adalah di bawah tiga agensi (joint venture) yang setiap daripadanya merupakan pemegang saham, iaitu Pertubuhan Kebajikan Anak Yatim Malaysia (PEYATIM) (50\%), Pertubuhan Kebajikan Anak Yatim Terengganu (PERKAYA) (30\%) dan Yayasan Kebajikan Negeri Terengganu (YAKIN) (20\%). PEYATIM selaku pemegang saham terbanyak dilantik sebagai pentadbir atau mutawalli UCB

63 Tengku Mahmud Mansor (YM. Profesor Dato' Dr, Pengerusi Lembaga Pengelola Universiti UCB, Pengerusi PEYATIM), dalam temu bual beliau dengan penulis pada 20 Jun 2017. 
adalah bertanggungjawab untuk memastikan dana wakaf yang dikumpulkan diurus dengan cekap dan berdasarkan pematuhan Syariah. Idea untuk melaksanakan konsep wakaf dalam UCB dipercayai dapat menjadi kayu pengukur kepada negeri-negeri lain di Malaysia. ${ }^{64}$ Walau bagaimanapun, tugas-tugas penjanaan dana wakaf dan perbelanjaan termasuk pemasaran UCB diuruskan oleh Yayasan Wakaf Pendidikan Anak Yatim Atau Miskin Malaysia (YAWATIM). YAWATIM Berhad yang ditubuhkan pada 2 November 2011 sebagai sebuah syarikat perniagaan murni dengan nombor pendaftaran 96651H menurut Seksyen 16 (4) Akta Syarikat 1965. Konsep ini menurut Siti Mashitoh Mahamood ${ }^{65}$ merupakan konsep usaha sama (joint venture), pihak-pihak yang terlibat dalam aktiviti wakaf boleh bekerjasama dengan kepakaran dan kemudahan sedia ada untuk memajukan wakaf di Malaysia. Aktiviti perwakafan tanah tapak kolej mula dijalankan pada tahun 2009 yang diluluskan oleh MAIDAM untuk memastikan segala aktiviti yang berkaitan dengan harta wakaf selari dengan Syariah. Ini kerana MAIDAM adalah pemegang amanah tunggal bagi semua jenis wakaf di negeri Terengganu. ${ }^{66}$ Kemudian wakaf ini dilancarkan pada tahun 2010 oleh Seri Paduka Baginda Yang Di-Pertuan Agong Tuanku Mizan Zainal Abidin. Perkara ini merupakan antara aktiviti bagi memastikan kelestarian wakaf itu sendiri.

\section{STRATEGI UCB DALAM MELESTARIKAN WAKAF MELALUI AKTIVITI KEUSAHAWANAN}

Aset (tanah) merupakan ekuiti nyata yang merupakan modal atau kekuatan bagi UCB. Tanah seluas 320 ekar yang telah dihibahkan oleh Kerajaan Negeri Terengganu dan didaftarkan di bawah kepemilikan UCB. Majlis Agama Islam dan Adat Melayu Terengganu (MAIDAM) telah meluluskan bahawa tanah hibah tersebut boleh dijual untuk didapatkan manfaatnya. Rohayati Hussin et al. ${ }^{67}$ mendapati bahawa faktor kepemilikan aset sendiri sebagaimana di UCB

${ }_{64}$ Mohammad Obaidullah, 'Waqf Development: Islamic Development Bank Experience,' 221-236.

65 Siti Mashitoh Mahamood, 'Pembentukan Dana Wakaf menurut Perspektif Syariah dan Undang-Undang serta Aplikasinya di Malaysia,' Jurnal Syariah, 15/2 (2007): 61-83.

66 Rohayati Hussin, Rusnadewi Abdul Rashid \& Noor Inayah Yaakub, 'Isuisu berkaitan Tanah Wakaf: Halangan kepada Pembangunan Institusi Wakaf Pendidikan Tinggi di Malaysia,' 16-23.

67 Rohayati Hussin, Rusnadewi Abdul Rashid \& Noor Inayah Yaakub, 'Isuisu berkaitan Tanah Wakaf: Halangan kepada Pembangunan Institusi Wakaf Pendidikan Tinggi di Malaysia,' 16-23. 
memberikan lebih banyak peluang untuk mengumpul dana wakaf. Universiti boleh menggunakan pengaruh dan autonominya untuk menentukan praktis perbelanjaan dari dana ini sama ada untuk tujuan menambahkan lagi dana atau membelanjakan dana tersebut. Dalam erti kata lain, universiti berhak menentukan hala tuju dana sumbangan ini yang terdiri daripada empat rukun iaitu pewakaf (al-wāqif), harta yang diwakafkan (al-mawqūf), penerima manfaat wakaf(al-mawqüf'alayh) dan penyataan wakafatau ikrar(al-ṣighah). ${ }^{68}$

Strategi pertama yang telah dijalankan di UCB adalah menjual tanah hibah seluas 320 ekar kepada masyarakat berdasarkan lot-lot (harga satu lot adalah RM 30) dan kemudian pembeli, iaitu staf UCB dan masyarakat mewakafkan semula tanah yang mereka beli tersebut kepada pihak UCB untuk dimanfaatkan sebagai bahagian daripada universiti. Wang hasil penjualan lot-lot tanah tersebut dimanfaatkan untuk pengelolaan aktiviti pendidikan di UCB. Setiap pembeli akan diberi maklum balas dengan pemberian Sijil Penghargaan yang dikeluarkan oleh PEYATIM. Secara purata YAWATIM berjaya mengumpul dana wakaf sekitar RM 4 hingga RM 5 juta pertahun. ${ }^{69}$ Strategi ini sama dengan yang dijalankan di Singapura iaitu menjual hartanah wakaf yang sedia ada dan kemudian tanah tersebut diwakafkan semula oleh pembeli kepada pihak yang menjual tersebut. Cara ini merupakan satu daripada lima strategi wakaf yang popular di Singapura. ${ }^{70}$ Kaedah terbaru yang akan dijalankan dalam masa terdekat di UCB adalah pengumpulan wakaf tunai dengan menggunakan kaedah tabung (celeng). Kaedah ini sejalan dengan Mohd Ali Muhamad Don ${ }^{71}$ untuk memperbanyakkan aktiviti promosi dan kempen bagi memperoleh dana wakaf tunai. Caranya ialah pihak pengurusan UCB akan membahagikan lima tabung, terutamanya kepada staf dalaman. Kemudian, tabung itu diisi dengan wang berapa pun jumlahnya termasuk wang syiling sehingga penuh kemudian diwakafkan kepada pihak UCB.

Strategi kedua bagi meningkatkan aset wakaf, pihak UCB telah melaburkan semula wang yang telah didapatkan daripada hasil penjualan lot-lot tanah

68 Majidah Zainudin, 'Perbezaan Wakaf, Sedekah, Hibah dan Zakat,' Buletin Yayasan Waqaf Malaysia, 2 (Julai-Disember 2013), 11.

69 Tengku Mahmud Mansor (YM. Profesor Dato' Dr, Pengerusi Lembaga Pengelola Universiti UCB,Pengerusi PEYATIM), dalam temu bual beliau dengan penulis pada 20 Jun 2017.

70 Shamsiah Abdul Karim, 'Contemporary Shari'a Compliance Structuring For the Development and Management of Waqf Asets in Singapore,' Kyoto Bulletin of Islamic Area Studies, 3/2 (2010), 143-154.

71 Mohd Ali Muhamad Don, 'Peranan Wakaf untuk Pembangunan Pendidikan Tinggi: Sejarah Silam dan Pelaksanaan di Malaysia,' (E-Prosiding 3rd International Conference on Arabic Studies and Islamic Civilization ICASIC2016, 14-15 Mac, Kuala Lumpur). 
wakaf dengan membeli aset-aset yang strategik. Wang ini tidak terhenti begitu sahaja tetapi dilaburkan semula dan diputar semula dengan membeli tanah yang mempunyai nilai yang tinggi. Strategi ketiga adalah membina bangunan komersial atau pusat keusahawanan di atas tanah wakaf seperti pasar raya atau tempat penginapan. Bagi menjana pendapatan dengan lebih baik, pasar raya tersebut akan disewakan kepada pelajar dan juga masyarakat. Kutipan wang sewa tersebut akan digunakan bagi aktiviti pendidikan UCB. Selanjutnya strategi keempat adalah terlibat dalam sektor perniagaan seperti restoran di Bandar Permaisuri yang dikelola oleh pensyarah dan pelajar Diploma Kulinari UCB. Pensyarah dan pelajar tersebut telah dilantik bagi menjalankan perniagaan makanan tersebut. Langkah ini juga bertujuan untuk melatih jiwa keusahawanan pelajar, sehingga pelajar tidak hanya belajar teori sahaja tetapi juga boleh mempraktikkan teori yang telah dipelajari. Terkini terdapat satu penambahan unit restoran di Kuala Terengganu yang dikelola oleh Fakulti Pengurusan Hospitaliti dan Pelancongan bekerja sama dengan PERKAYA. Pihak UCB di bawah Fakulti Sains Informatik (FSI) juga telah melancarkan program Tekno-Usahawan melalui pemasaran digital (UNIBESTNIAGA. COM) bagi menjana pendapatan universiti dan pelajar serta masyarakat setempat.

Strategi kelima, pihak UCB juga telah mula membangunkan dan memanfaatkan aset (tanah) yang sedia ada bagi aktiviti pertanian dan penternakan. Kawasan pertanian dan penternakan yang dikenali dengan 'Trigona' merupakan lahan yang dimanfaatkan bagi aktiviti pertanian dan penternakan. Hasil daripada pertanian dan penternakan ini dimanfaatkan untuk operasional UCB. Hartanah wakaf dimanfaatkan untuk tujuan pertanian seperti penanaman pokok seperti nanas md2 dan aktiviti perikanan yang dikelola oleh Fakulti Agrosains UCB. Strategi keenam, UCB juga telah membuka peluang kepada masyarakat untuk berwakaf dalam pelbagai bentuk, seperti wakaf penyelidikan dan harta intelek (tesis), buku-buku teks, wakaf fasiliti gazebo dan yang akan dilaksanakan adalah wakaf jalan. Keadaan ini membuktikan tiada eksklusifisme dalam berwakaf kerana seringkali wakaf dikaitkan dengan golongan kaya sahaja, padahal setiap orang boleh berwakaf.

Kesemua aktiviti wakaf ini dikawal selia secara ketat oleh YAWATIM, MAIDAM dan Penasihat Syariah yang ditunjuk khas bagi mengawal pelaksanaannya agar aktiviti wakaf tidak bertentangan dengan syarak. Pengawalan sangatlah ketat sehingga semua pihak mengetahui semua aktiviti kewangan yang berlaku. Hal ini ditegaskan oleh pihak pengerusi PEYATIM: ${ }^{72}$

72 Tengku Mahmud Mansor (YM. Profesor Dato' Dr, Pengerusi Lembaga Pengelola Universiti UCB, Pengerusi PEYATIM), dalam temu bual beliau dengan penulis pada 20 Jun 2017. 
"Kita akan memastikan setiap sen dana yang dibelanjakan mestilah digunakan untuk tujuan yang betul. Dalam hal ini bagi setiap sen pengeluaran wang mestilah dengan persetujuan Pengerusi YAWATIM."

Jawatankuasa ini diketuai oleh seorang Pengerusi yakni YAWATIM bagi mengawal kewangan. Fungsi YAWATIM tidak hanya untuk memasarkan tanah wakaf bagi menjana pendapat tetapi juga mengawal dana hasil penjualan tersebut. Untuk memastikan kawalan berjalan baik menurut Pengerusi PEYATIM lagi:

"Setiap tiga bulan akan diadakan pertemuan bagi tujuan pengawalan tersebut yang turut dihadiri oleh Majlis Agama dan Adat Istiadat Melayu (MAIDAM), tokoh agama sebagai Penasihat Syariah dan ketiga-tiga lembaga pemegang saham UCB. Selain pengurusan yang baik juga pengawalan atau controlling melalui YAWATIM, MAIDAM dan penasihat tokoh agama dari Johor sebagai pakar rujuk. Ada komite untuk mengawal, bahkan pengeluaran satu sen pun haruslah diketahui oleh ketua komite bagi tujuan transparansi. PEYATIM akan bersidang atau mesyuarat sekali tiga bulan untuk membentangkan penjanaan dana wakaf dan segala perbelanjaan untuk menciptakan transparansi. YAWATIM selain mempromosikan wakaf, ia juga mengawal kewangan wakaf tersebut. Kontrol sangatlah ketat sehingga tahu semua aktiviti kewangan yang berlaku."

Kawalan atau monitoring adalah merupakan faktor penting dalam suatu urus tadbir sebuah institusi. Menurut Nur Farhana Dahalan et al., ${ }^{73}$ sistem tadbir urus yang baik harus terdiri daripada satu sistem struktur, operasi dan mengawal sebuah institusi tersebut. Risiko dalam urus tadbir termasuklah masalah integriti, keyakinan masyarakat merupakan antara risiko dalam pengurusan wakaf IPT di Malaysia. Oleh itu, penting bagi UCB memastikan bahawa setiap dana wakaf dapat digunakan secara bertanggungjawab.

73 Nur Farhana Dahalan, Rahisam Ramli, Roslina Hashim, Nur Yuhanis Ismon \& Shahrina Romli, 'Risiko Pengurusan Dana Wakaf untuk Institusi Pendidikan Tinggi di Malaysia: Satu kerangka Konseptual,' Jurnal 'Ulwan, 1 (2016): 164178. 
Strategi-strategi yang dijalankan di UCB ini selari dengan cadangan pengkaji seperti Zakaria Bahari, ${ }^{74}$ Baharuddin Sayin dan Muhammad Hamizan Abd Hamid ${ }^{75}$ agar pihak pengurusan wakaf tidak hanya bergantung kepada sumbangan daripada orang ramai dalam menyelenggarakan harta wakaf, tetapi perlu ada inisiatif dalam meningkatkan penghasilan harta wakaf terutamanya yang bersifat ekonomi dan perniagaan. Oleh itu, kelestarian wakaf mestilah bermula daripada aktiviti-aktiviti seperti yang dikemukakan di atas. Bentuk wakaf melalui fasa kepelbagaian sesuai mengikut perubahan zaman. Strategi ini merupakan kaedah yang dipraktikkan bagi tujuan memproduktifkan aset wakaf seperti yang dinyatakan oleh Hydzulkifli Hashim dan Asmak Abd Rahman ${ }^{76}$ melalui tiga kaedah. Pertama, menyewakan aset wakaf sedia ada dan hasilnya boleh disalurkan kepada penerima manfaat wakaf atau membangunkan harta wakaf yang lain. Kedua, melaksanakan aktiviti penternakan dan pertanian di atas tanah wakaf. Ketiga, melakukan aktiviti yang bersifat komersial.

Institusi wakaf wajar bergerak seiring dengan melakukan transformasi pada aspek pengurusan dan pentadbiran bagi mengatasi masalah sedia ada dan menjamin potensi wakaf dalam struktur sistem ekonomi Islam. Pengurusan dan pentadbiran institusi wakaf yang profesional, amanah dan sistematik dengan menggunakan pendekatan semasa dan berkesan yang berpaksikan kepada hukum syarak memberi ruang luas kepada pembangunan harta wakaf. ${ }^{77}$ Salah satu jalan keluar yang sesuai dalam memastikan kelestarian wakaf adalah dengan mensinergikan keusahawanan dan wakaf itu sendiri. Pengurusan harta wakaf perlu melibatkan aktiviti keusahawanan agar memberikan pulangan yang maksimal, pada masa yang sama harta wakaf tersebut tetap kekal.

74 Zakaria Bahari \& Ahmad Shaifful Anuar Ahmad Shukor, 'Pemerkasaan Tadbir Urus Wakaf Pendidikan Tinggi Malaysia,' (Kertas Kerja, International Conference on Social, Political, Governmental \& Communication Scienses (ICSPGCS), Ahmad Zahuri Hall, Universitas Muhammadiyah, Jember, Jawa Timur, Indonesia, 2017), 28-44.

75 Baharuddin Sayin \& Muhammad Hamizan Abd Hamid, 'Wakaf Tunai: Satu Cadangan Penguatkuasaan Perkara 11 (2) Perlembagaan,' (Kertas kerja, International Conference on Waqf 2015 (ICW2015), Kuala Terengganu, Universiti Sultan Zainal Abidin, 2015).

76 Hydzulkifli Hashim \& Asmak Abd Rahman, 'Aplikasi Sukuk dalam Melestarikan Aset Wakaf: Pengalaman Pemegang Amanah Terpilih,' Jurnal Syariah, 21/2 (2013): 89-116.

77 Abdul Halim Ramli \& Kamarulzaman Sulaiman, 'Pembangunan Harta Wakaf: Pengalaman Negara-Negara Islam,' (Kertas Kerja, Konvensyen Wakaf Kebangsaan, Hotel Legend, Kuala Lumpur, 12-14 September 2006). 


\section{KESIMPULAN}

Kepentingan wakaf dalam pendidikan tinggi tidak dapat dinafikan lagi. Wakaf tidak hanya dapat memperkasakan ekonomi ummah tetapi juga terbukti dapat memperkasakan IPT. Wakaf pendidikan tinggi ini dianggap sebagai salah satu solusi yang berpotensi untuk memastikan pendidikan tetap lestari dan dapat dinikmati oleh seluruh masyarakat. Persoalan yang selalu dibincangkan adalah tentang isu kelestarian. Isu penggunaan dana yang berasal dari pemberian masyarakat seperti wakaf dalam Islam adalah bagaimana dana tersebut dapat lestari dan kekal. Konsep menggerakkan dana untuk pembangunan tidak boleh bersifat sementara, sebaliknya ia perlu dilakukan dalam pelbagai cara agar ianya berkekalan. Dana wakaf dapat dimanfaatkan secara optimum melalui aktiviti-aktiviti keusahawanan yang berpandukan kepada Syarak. Antara langkah dan strategi yang telah dijalankan UCB bermula dengan menetapkan struktur dalam organisasi wakaf yang jelas bagi memastikan pengurusan dana wakaf ini dapat dijalankan dengan baik dan lestari. Terdapat enam strategi utama UCB bagi memastikan kelestarian wakaf. Pertama menjual tanah hibah yang dimiliki UCB, kemudian pembeli mewakafkan kepada UCB. Kedua adalah melaburkan dana wakaf pada pelaburan yang halal lagi menguntungkan. Ketiga adalah membina bangunan komersial atau pusat keusahawanan di atas tanah wakaf seperti pasar raya atau tempat penginapan. Keempat, membuka aktiviti perniagaan dengan melibatkan pensyarah dan pelajar. Strategi kelima, pihak UCB juga telah mula membangunkan dan memanfaatkan tanah bagi aktiviti pertanian dan penternakan. Strategi keenam, UCB juga telah membuka peluang kepada masyarakat untuk berwakaf dalam pelbagai bentuk. University College Bestari juga telah menubuhkan Bahagian Pembangunan Usahawan dan Pengajian Bahasa (BestPEC) bertujuan membekali pelajar dan pensyarah dengan pengetahuan dan pengalaman keusahawanan sehingga mereka bukan hanya sekadar menguasai teori, tetapi juga mempunyai kemahiran keusahawanan. Aktiviti-aktiviti ini terbukti berkesan dengan lestarinya operasional UCB sebagai IPTS berasaskan wakaf selama lebih dari 12 tahun.

\section{RUJUKAN}

Abdul Halim Ramli \& Kamarulzaman Sulaiman, 'Pembangunan Harta Wakaf: Pengalaman Negara-Negara Islam,' (Kertas Kerja, Konvensyen Wakaf Kebangsaan, Hotel Legend, Kuala Lumpur, 12-14 September 2006).

Abdul Hamid Mar Iman \& Mohammad Tahir Sabit Mohammad, Waqf Property: Concept, Management, Development and Financing (Johor Bahru: Penerbit UTM, 2014). 
Abī al-Ḥusayn Muslim bin al-Hajjāj bin Muslim al-Qushayrī al-Naysabūrī, Șaḥịh Muslim, vol. 3 (Bayrūt: Dār al-Kutub al-'Ilmiyyah, 1991).

Ahmad Shaifful Anuar Ahmad Shukor, Potensi Wakaf Pendidikan Tinggi di Malaysia (Kuala Lumpur: Dewan Bahasa dan Pustaka, 2015).

Arkib University College Bestari (UCB), Profil UCB (Terengganu: Jabatan Pendaftar University College Bestari (UCB), 2016).

Asharaf Mohd Romli \& Mustafa Omar Mohamad, 'An Overview of Public Funding for Higher Learning Education in Malaysia and the Prospect of Waqf Funding,' (Waqf Workshop, Contemporary Role of Higher Education, Al-Bukhari International University, Alor Star, 2013), 1-20.

Asmak Ab Rahman, 'Peranan Wakaf dalam Pembangunan Ekonomi Umat Islam dan Aplikasinya di Malaysia,' Jurnal Syariah, 17/1 (2009): 113152.

Azri Ahmad, Syarqawi Muhammad \& Mohd Asyran Safwan Kamaruzaman, 'Education Development Through Waqf,' (Kertas kerja, 3rd International Conference on Islam and Higher Education (3rd ICIHE), Pahang State Foundation Complex, Kuantan, Malaysia, 1-2 Oktober 2012).

Baharuddin Sayin \& Muhammad Hamizan Abd Hamid, 'Wakaf Tunai: Satu Cadangan Penguatkuasaan Perkara 11 (2) Perlembagaan,' (Kertas kerja, International Conference on Waqf 2015 (ICW2015), Kuala Terengganu, Universiti Sultan Zainal Abidin, 2015).

Chowdhury, M.S.R. et al., 'Economics of Cash Waqf Management in Malaysia: A Proposed Cash Waqf Model for Practitioners and Future Researchers,' African Journal of Business Management, 5/30 (2011): 12155-12163.

Farra Munna Harun, Bayu Taufiq Possumah, Muhammad Hakimi Mohd Shafiai, Fidlizan Muhammad, Azila Abdul Razak \& Mohd Yahya Mohd Hussin, 'Issues and Economic Role of Waqf in Higher Education Institution: Malaysian Experience,' Journal of Islamic Economics, 8/1 (2014): 149-168.

Gnyawali R. Devy \& Fogel S. Daniel, 'Environments for Entrepreneurship Development: Key Dimensions and Research Implications,' Entrepreneurship Theory and Practice, 18/4 (1994): 43-62.

Hans Landstrom, Pioneers in Entrepreneurship and Small Business Research (New York: Springer Science-Business Media, Inc, 2005).

Hansmann H., 'Why Do Universities Have Endowments?', The Journal of Legal Studies, 19/1 (1990): 3-42. 
Hisham Sabri, Khairil Faizal Khairi, Mohamad Yazis Ali Basah, Nurhidayah Laili, Muhamad Ridhwan Abd. Aziz \& Nurhidayah Damiron, 'Sumbangan Manfaat Wakaf Terhadap Pembangunan Ummah di Malaysia: Satu Analisis dalam Pengurusan Johor Corporation (jcorp)Waqaf An-nur Corporation Berhad (WANCORP),' (2 ${ }^{\text {nd }}$ International Research Management \& Innovation Conference IRMIC 2015, Langkawi, 26-27 Ogos).

Hydzulkifli Hashim \& Asmak Abd Rahman, 'Aplikasi Sukuk dalam Melestarikan Aset Wakaf: Pengalaman Pemegang Amanah Terpilih,' Jurnal Syariah, 21/2 (2013): 89-116.

Jabatan Wakaf, Zakat dan Haji, Manual Pengurusan Istibdal Wakaf (Putrajaya: Jabatan Wakaf, Zakat dan Haji, 2010).

K. Krippendorff, Content Analysis: An Introduction to its Methodology, 3rd. ed. (Thousand Oaks. London: SAGE Publication, 2013).

Kartini Aboo Talib@Khalid, Nidzam Sulaiman, Wan Kamal Mujani \& Ermy Azziaty Rozali, 'Membiayai Pendidikan Tinggi Menerusi Endowmen: Kewibawaan Model Hibrid Harvard,' Malaysia Journal of Society and Space, 11/4 (2015): 121-131.

Kementerian Kewangan Malaysia, Bajet 2016 (Kuala Lumpur: KKM, 2016).

Kementerian Pendidikan Tinggi, Pelan Tindakan Keusahawanan Institusi Pendidikan Tinggi 2016-2020 (Kuala Lumpur: KPT, 2016).

Maffuza Salleh \& Noor Syahida Abdul Rahman, 'Wakaf Pendidikan di Malaysia: Satu Tinjauan,' (Kertas kerja, International Research Management and Innovation Conference (IRMIC2014), Kuala Lumpur, 17-18 November 2014).

Majidah Zainudin, 'Perbezaan Wakaf, Sedekah, Hibah dan Zakat,' Buletin Yayasan Waqaf Malaysia, 2 (Julai-Disember 2013).

Mohammad Obaidullah, 'Waqf Development: Islamic Development Bank Experience,' (Kertas kerja, Seminar Wakaf Kebangsaan 2014, Hotel Istana Kuala Lumpur, 7-8 Disember 2014).

Mohamad Tahir Sabit Mohammad \& Abdul Hamid Mar Iman, "Obstacles of the Current Concept of Waqf to the Development of Waqf Properties and the Recommended Alternative," Malaysian Journal of Real Estate, vol. 1 (2006): 27-38.

Mohd Ali Muhamad Don, 'Peranan Wakaf untuk Pembangunan Pendidikan Tinggi: Sejarah Silam dan Pelaksanaan di Malaysia,' (E-Prosiding 3rd International Conference on Arabic Studies and Islamic Civilization ICASIC2016, 14-15 Mac, Kuala Lumpur). 
Mohd Syakir Mohd Taib, Wan Kamal Mujani, Ermy Azziaty Rozali \& Kartini AbooTalib@Khalid, 'Perkembangan Wakaf Pendidikan Tinggi di Malaysia Development of Waqf Higher Education in Malaysia,' International Journal of West Asian Studies, 9/1 (2017): 82-92.

Mokhtar Ismail, Hairullfazli Muhammad Som, Mohd. Isa Mohd. Deni \& Muna Sulaiman, 'Model Operasi Wakaf Pendidikan di Malaysia,' International Conference on Cash Waqf (ICCW 2015) (Sepang: t.p., 2015).

Monzer Kahf, 'Financing the Development of Awqaf Property,' (Kertas Kerja, Seminar Development of Awqaf, organized by IRTI, Kuala Lumpur, 1998).

Muhammad 'Alī al-Shawkānī, Nayl al-Awțār, vol. 6 (Manșūrah: Dār al-Wafā', 2005).

Muḥammad 'Alī al-Shawkān̄̄, Nayl al-Awțār, vol. 6 (Qāhirah: Maktabah wa Matba'ah Mușțafā al-Bābī al-Ḥalābī Awlādih, t.t.).

Muḥammad Isma'il al-Bukhārī, Șaḥị̣ Bukhārī (Bayrūt: Dār Ibn Kathīr, 2002).

Mujtaba Khalid, 'Waqf as a Socially Responsible Investment Instrument: A Case for Western Countries,' European Journal of Islamic Finance, 1 (2014): 1-6.

Murat Çizakça, 'A Waqf in History and its Implications for Modern Islamic Economies,' Islamic Economic Studies, 6/1 (1998): 43-70.

Noor Hisham Md Nawi \& Burhan Che Daud, 'Sinergisme Konsep Wakaf Pendidikan dan Gagasan Keusahawanan Sosial Islam: Wasilah Pembangunan Komuniti Intelektual Mandiri,' dalam Sinergisme Wakaf Pendidikan Tinggi di Malaysia (Shah Alam: Institut Kajian Zakat Malaysia dan Universiti Teknologi MARA, 2016), 85-100.

Noor Inayah Yaakub, 'The Transformation of The Role of Waqf In The Higher Learning Education in Malaysia: A New Paradigm For Islamic Financial Institutions,' (Kertas kerja, 11 th Kuala Lumpur Islamic Finance Forum, Kuala Lumpur City Centre, 11-12 November 2014).

Norashidah Hashim, et al., Asas Keusahawanan (Sintok: Pusat Pendidikan Profesional dan Lanjutan (PACE), Universiti Utara Malaysia, 2009).

Norfadhilah Nasharudin \& Halimah Harun, 'Aspirasi Kerjaya Keusahawanan dalam Kalangan Pelajar Institusi Pengajian Tinggi Awam,' Jurnal Pendidikan Malaysia, 35 (2010): 11-17.

Nur Farhana Dahalan, Rahisam Ramli, Roslina Hashim, Nur Yuhanis Ismon \& Shahrina Romli, 'Risiko Pengurusan Dana Wakaf untuk Institusi Pendidikan Tinggi di Malaysia: Satu Kerangka Konseptual,' Jurnal 'Ulwan, 1 (2016): 164-178. 
Ooi, Y. K., Habshah, B., Shuhymee, A. \& Norashidah, H., 'Persepsi Pensyarah untuk Mengajar Kursus Keusahawanan: Satu Kajian Empirikal di Universiti Utara Malaysia,' (Kertas kerja, 2nd International Seminar on Quality and Affordable Education ISQAE, Johor Bahru, 7-10 Oktober 2013).

Raja Nor Ashikin Raja Ramli \& Nor 'Adha Abd Hamid, 'Kelestarian Wakaf dalam Membangunkan Institusi Pendidikan: Kajian Awal,' (Kertas kerja, International Conference on Postgraduate Research, Kuala Lumpur, 1-2 Disember 2014).

Rohayati Hussin, Rusnadewi Abdul Rashid \& Noor Inayah Yaakub, 'Isu-isu berkaitan Tanah Wakaf: Halangan kepada Pembangunan Institusi Wakaf Pendidikan Tinggi di Malaysia,' (Kertas kerja, Waqf Round Table Conference-IKAZ/ACIS, 12 Februari 2015).

Sabitha Marican, Penyelidikan Sains Sosial: Pendekatan pragmatic (Malaysia: Prentice Hall Pearson, 2005).

Shamsiah Abdul Karim, 'Contemporary Shari'a Compliance Structuring For the Development and Management of Waqf Asets in Singapore,' Kyoto Bulletin of Islamic Area Studies, 3/2 (2010): 143-154.

Siti Inayatul Faizah, Nisful Laila \& Achsania Hendratmi, Productive Waqf as One of the Problematic to Unemployment in Indonesia (Surabaya: SS \& MLB, 2013).

Siti Mashitoh Mahamood \& Asmak Ab Rahman, 'Financing Universities Through Waqf, Pious Endowment: Is It Possible?,' Humanomics, 31/4 (2015): 430-453.

Siti Mashitoh Mahamood, 'Pembentukan Dana Wakaf menurut Perspektif Syariah dan Undang-Undang serta Aplikasinya di Malaysia,' Jurnal Syariah, 15/2 (2007): 61-83.

Siti Zakiah Ali \& Hairunnizam Wahid, 'Peranan dan Kepentingan Dana Wakaf Institusi Pendidikan Tinggi di Malaysia,' (Kertas kerja, Persidangan Kebangsaan Ekonomi Malaysia ke-9 (PERKEM ke-9), Kuala Terengganu, 2014).

Suraiya Ishak \& Ahmad Raflis Che Omar, 'Konsep dan Amalan Perniagaan Sosial di Malaysia,' Jurnal Manusia dan Masyarakat, 2/1 (2015): 55-70.

Syahnaz Sulaiman \& Aznan Hasan, 'Strategi Pembangunan dan Pelaburan Wakaf secara Lestari Menurut Perspektif Syariah,' Jurnal Syariah, 24/2 (2016): 237-270. 
Syahrina, A., Habshah, B., Ooi, Y. K. \& Norashidah, H., 'Kajian Keberkesanan Graduan Ijazah Sarjana Muda Keusahawanan Universiti Utara Malaysia,' (Kertas kerja, Seminar Kebangsaan Pembangunan Keusahawanan, Kuala Lumpur, 8-9 Disember 2009).

Tham, Siew Yean, 'Exploring Access and Equity in Malaysia's Private Higher Education,' ADBI Working Paper Series, 280 (2011), 1-21.

Utusan Online, 'Dana Wakaf Kukuhkan Dana Universiti,' http://www. utusan.com.my/berita/nasional/dana-wakaf-kukuhkan-danauniversiti-1.400189, dicapai pada 27 Oktober 2016.

Utusan Online, 'UCB raih anugerah terbaik di Seoul,' http://www.utusan.com. my/pendidikan/kampus/ucb-raih-anugerah-terbaik-di-seoul-1.552665, 14 November 2017, dicapai pada 15 Januari 2018

V.J. Duriau, R.K. Reger \& M.D. Pfarrer, 'A Content Analysis of the Content Analysis Literature in Organization Studies: Research Themes, Data Sources, and Methodological Refinements,' Journal of Organizational Research Methods, 10/1 (2007): 5-34.

Zakaria Bahari \& Ahmad Shaifful Anuar Ahmad Shukor, 'Pemerkasaan Tadbir Urus Wakaf Pendidikan Tinggi Malaysia,' (Kertas Kerja, International Conference on Social, Political, Governmental \& Communication Scienses (ICSPGCS), Ahmad Zahuri Hall, Universitas Muhammadiyah, Jember, Jawa Timur, Indonesia, 2017), 28-44.

Zakariya Man \& Salihu Abdulwaheed, 'A New Dimension in the Mobilization of Waqf Funds for Educational Development,' Kuwait Chapter of Arabian Journal of Business and Management Review, 1/1 (2011): 155175.

\section{Temu bual}

Tengku Mahmud Mansor (YM. Profesor Dato' Dr, Pengerusi Lembaga Pengelola Universiti UCB,Pengerusi PEYATIM), dalam temu bual beliau dengan penulis pada 20 Jun 2017. 